\title{
Seismic and Time History Performance of RCC Framed Buildings with and without Passive Energy Dissipators
}

\author{
Sai Gowtham Dasari, K. Srinivasa Rao
}

\begin{abstract}
Base isolation is an effective way to protect large structures from earthquake damage. It is a costly approach, as the entire structure must be supported on elastomeric or sliding bearings. Viscous dampers distributed throughout an otherwise conventional structure can achieve the same result at a significantly lower cost. Dampers are used to resist lateral forces coming on the structure. Dampers are the energy dissipating devices which also resist displacement of Reinforced Concrete (RC) buildings during an earthquake. These dampers help the structure to reduce buckling of columns thereby increasing the stiffness of the structure. During earthquakes, multi-storeyed buildings get damaged and as a result, large deformation occurs. Dampers reduce vibration and deformation of structural elements during an earthquake. Retrofitting buildings with fluid viscous dampers (FVDs) can improve Interstorey drifts and floor accelerations.

In the present study, an RC framed building is modelled and analysed under Southern Sumatra and Chile earthquakes to evaluate the performance of the structure and its elements with and without energy dissipators. For the study, a model $(G+19)$ with and without energy dissipators is modelled in ETABS. The seismic force is applied based on the time history data of the models pertaining to Southern Sumatra and Chile Earthquake. Response Spectrum analysis has been carried out to find the lateral displacements, storey shear and Base shear for the model with and without dampers. The lateral displacement, storey drift, storey shear and Base shear are found to less for the model with Linear FVDs when compared to the model with Non-Linear FVDs and without FVDs.
\end{abstract}

Keywords: ETABS, Non-Linear FVDs and without FVDs.

\section{INTRODUCTION}

Supplemental passive damping systems can considerably improve the seismic performance of structures by decreasing drifts and inelastic deformation demands on the fundamental lateral load resisting system [1]. The fluid viscous damper is one type of passive energy dissipation systems that are used in the absorption and dissipation of the earthquake input energy. For the past few decades, the use of fluid viscous dampers has become increasingly prevalent in new and retrofit constructions excited by wind and earthquake loads because these devices have the ability to dissipate earthquake-induced energy into structures [2,3]. These dampers are made up of a cylinder and a stainless steel piston.

Revised Manuscript Received on February 05, 2020.

* Correspondence Author

Sai Gowtham Dasari*, field of Transportation and Structures, Visakhapatnam, India.

Dr. Srinivas Rao Killamsetti, Professor, Department of Civil Engineering, Andhra University, India.

(C) The Authors. Published by Blue Eyes Intelligence Engineering and Sciences Publication (BEIESP). This is an open access article under the CC BY-NC-ND license (http://creativecommons.org/licenses/by-nc-nd/4.0/)

The cylinder is filled with incompressible silicone fluid that is divided into two compartments by a piston. The damper is activated by the stream of silicone fluid between the chambers at the opposite ends of the unit through small orifices. By limiting the velocity with which the fluid can move (via the valve), a velocity-dependent-resisting force is developed. The force, $\mathrm{F}$, in an FVD, is computed as: $\mathrm{F}=\mathrm{C} \times$ $|v| \alpha \times \operatorname{sgn}(v)(1)$

where $\mathrm{F}$ is the damping force,

$\mathrm{v}$ is the velocity,

$\mathrm{C}$ is a damping coefficient,

$\alpha$ is a damping exponent that adopts the value of 1.0 for linear viscous dampers and a value between 0.1 and 2 for nonlinear viscous dampers and sgn is the signum function [4]. Experimental and analytical studies have shown that the use of viscous dampers inside the structures or between adjacent structures can control and improve the performance of structures such as the motion amplitude, inter-story drifts and absolute accelerations generated by earthquake actions [5-11]. Constantinou and Symans [5,6] and Tsai et al. [9] have carried out experimental and analytical research on the seismic performance of steel buildings with FVDs. Uriz and Whittaker [11] found that the use of FVDs with the equivalent viscous damping of $40 \%$ of critical damping caused a decrease in the displacement of the frame. Dicleli and Mehta [12] compared the seismic performance of steel chevron braced frames (CBFs) with and without fluid viscous dampers (FVDs) in terms of intensity and frequency characteristics of the ground motion and FVD parameters. Choung-Yeol Seo et al. [13] designed a steel structure with $100 \%$ and $75 \%$ of design base shear using linear damper; then, it was compared with a structure without dampers. They found that the use of linear damper could improve the performance of the structure and reduce the probability of collapse. Some studies have been conducted using new configurations both vertical and horizontal displacements at the ends of dampers were effective for the obtained responses. Previous studies have demonstrated that the use of both linear and nonlinear viscous dampers could improve the seismic performance of structures. Nevertheless, the comparison between structures with linear and nonlinear dampers and the same damping ratio is scarce. FEMA 451 [31] comprises these dampers and shows that the nonlinear FVD has better performance and could dissipate more energy than the linear FVD. In this comparison, only $\alpha$ is changed, and C is kept constant. According to FEMA 273 and Hwang et al. [30], for the same damping ratio, damping coefficient is different for linear and nonlinear FVDs. Thus, we cannot compare the seismic performance of linear and nonlinear FVDs only by changing their damping exponents. 
To model a damper in SAP 2000, a section of damper type was used and assigned to a Link element. It is noteworthy that to prevent subsequent convergence issues; it is better to assign low mass to the damper.

\section{A. Classification of Energy dissipators}

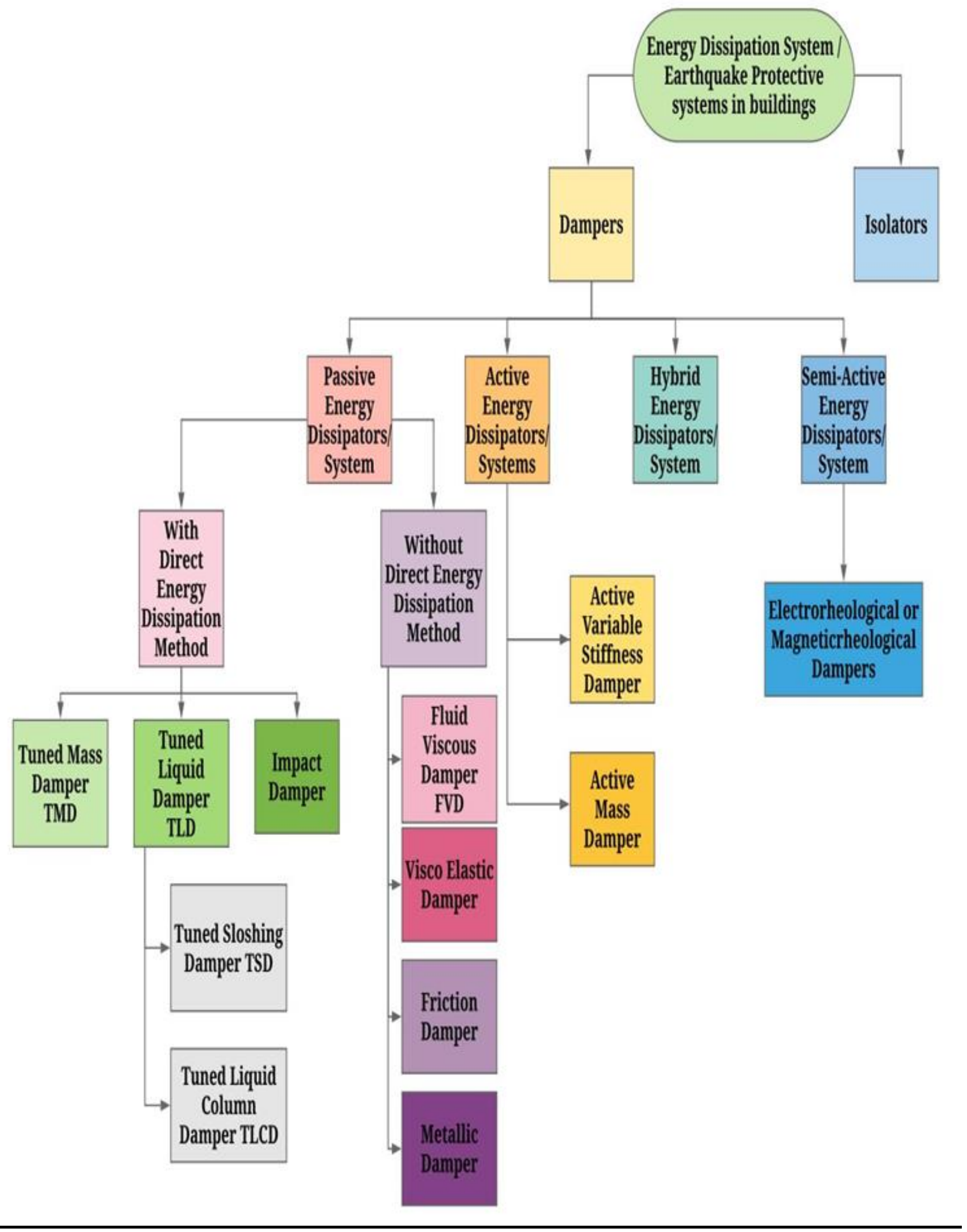




\section{METHODOLOGY}

A G+19 Reinforced Cement Concrete (RCC) framed structure with a plan area of $\mathbf{1 3 2 5 . 6}$ square metres is used for the present study. The $\mathrm{G}+19$ structure is designed for residential purpose. The plan and elevation of the G+19 building considered for the study have been shown in figure 2 and figure 3.

\section{A. Modelling in ETABS}

$>$ In the present study, a live RCC Building plan is taken and drafted in AUTOCAD 2018. It is then imported into ETABS and analysed as per the Indian Standards. This structure is assumed to be built in Bhuj, Gujarat which comes under Seismic Zone V and Cyclone Prone Area.

$>$ The structure is analysed for Seismic Response Spectrum, Wind \& Earthquake loads in the form of Time History in three different models:

- Model without energy dissipators

- A model with energy dissipators - Linear Fluid Viscous Dampers (FVDs)

- A model with energy dissipators - Non-Linear Fluid Viscous Dampers (NFVD).

\section{AA. GEOMETRIC DETAILS}

- $\quad$ Plan: 32.74 m X 40.49 m

- Type of Structure: SMRF

- Type of Building: Regular in Plan

- $\quad$ Storey Height: $3.0 \mathrm{~m}$

- No of Storeys: G +19 (20)

\section{AB. MATERIAL PROPERTIES}

- Grade of Concrete: M30

- Grade of Steel: Fe500

- The density of Concrete: $25 \mathrm{kN} / \mathrm{m}^{3}$

- The density of Steel: $78.5 \mathrm{kN} / \mathrm{m}^{3}$

- Elastic Modulus of concrete, $\mathrm{E}_{\mathrm{c}}=2.7386$ x 107 $\mathrm{kN} / \mathrm{m}^{2}$

- $\quad$ Elastic Modulus of Steel, $E_{s}=2 \times 108 \mathrm{kN} / \mathrm{m}^{2}$

- Poisson's Ratio of Concrete, $\mu_{\mathrm{c}}=0.175$

- Poisson's Ratio of Steel, $\mu_{\mathrm{s}}=0.3$

\section{AC. SECTION PROPERTIES}

- $\quad$ Primary Beam: 300 mm x 450 mm

- Secondary Beam: 230 mm x 400 mm

- Primary Column:450 mm x $700 \mathrm{~mm}$

- Secondary Column: 450 mm x 600 mm

- $\quad$ Slab:125 mm thick

\section{AD. LOAD DETAILS}

- Dead Load:

- Wall Load: $1.5 \times 19.2 \times 3 \times 0.23=19.872 \mathrm{kN} / \mathrm{m} \approx$ $20 \mathrm{kN} / \mathrm{m}$ (IS 875-P1-1987)

- Floor Loads: $6.1875 \mathrm{kN} / \mathrm{m}^{2} \approx 7 \mathrm{kN} / \mathrm{m}^{2}$ (IS 875P1-1987)

\# Slab: $1.5 \times 0.125 \times 25=4.6875 \mathrm{kN} / \mathrm{m}^{2}$

* Floor Finish (Water Proofing and Marbles): $1.5 \times 1=1.5 \mathrm{kN} / \mathrm{m}^{2}$

- $\quad$ Live Load: $1.5 x 2=3 \mathrm{kN} / \mathrm{m}^{2}$ (IS 875-P2-1987)

- Earthquake load in $\mathrm{X}$ and $\mathrm{Y}$ Direction as per IS1893: Part 1-2016

- $\quad$ Wind load as per IS875-Part 3-2015

- $\quad$ Time History Analysis of the structure

\section{AE. SEISMIC PROPERTIES}

- Seismic Zone: V, Zone Factor $(Z)=0.36$ (Bhuj, Gujarat)

- $\quad$ Response Reduction Factor(R) $=5$

- $\quad$ Importance Factor(I) = 1.5

- $\quad$ Soil Type: II

- Damping Ratio: 0.05

AF. TIME HISTORY ANALYSIS EARTHQUAKE DETAILS

- Southern Sumatra, Indonesia, 12-09-2007,8.4 Magnitude

- Iquique, Chile Earthquake, 01-04-2014, 8.2 Magnitude

AG. LINK PROPERTIES-FLUID VISCOUS DAMPER

- Translational Mass: $1000 \mathrm{~kg}$

- Weight of Damper: $0.1 \mathrm{kN}$

- Linear Properties:

$>$ Effective Stiffness: $300 \mathrm{kN} / \mathrm{mm}$

$>$ Effective Damping: $12 \mathrm{kN}-\mathrm{s} / \mathrm{mm}$

- Non-Linear Properties:

$>$ Stiffness: $300 \mathrm{kN} / \mathrm{mm}$

$>$ Initial Damping Coefficient: $1 \mathrm{kN}-\mathrm{s} / \mathrm{mm}$

$>$ Yielded Damping Coefficient: 6 kN-s/mm

$>$ Linear Force Limit: $1 \mathrm{kN}$

\section{AH. WIND LOAD PROPERTIES}

- Wind Speed, $\mathrm{V}_{\mathrm{b}}: 50 \mathrm{~m} / \mathrm{s}$ (Bhuj, Gujarat) (IS 875 Part-3 2015)

- $\quad$ Risk Coefficient, $\mathrm{k}_{1}: 1$

- $\quad$ Terrain Category: 3, $\mathrm{k}_{2}=1.136$

- Topography, $\mathrm{k}_{3}: 1$

- $\quad$ Importance Factor, $\mathrm{k}_{4}=1.3$

AI. Considering all type of combinations as per IS 875 Part 5 and IS 1893:2016, the worst combination from performance point has to be taken. For the analysis, one load combination i.e., $1.5\left[\mathrm{DL} \pm\left(\mathrm{EL}_{\mathrm{x}} \pm 0.3 \mathrm{EL}_{\mathrm{y}}\right)\right]$ is the worst combination.

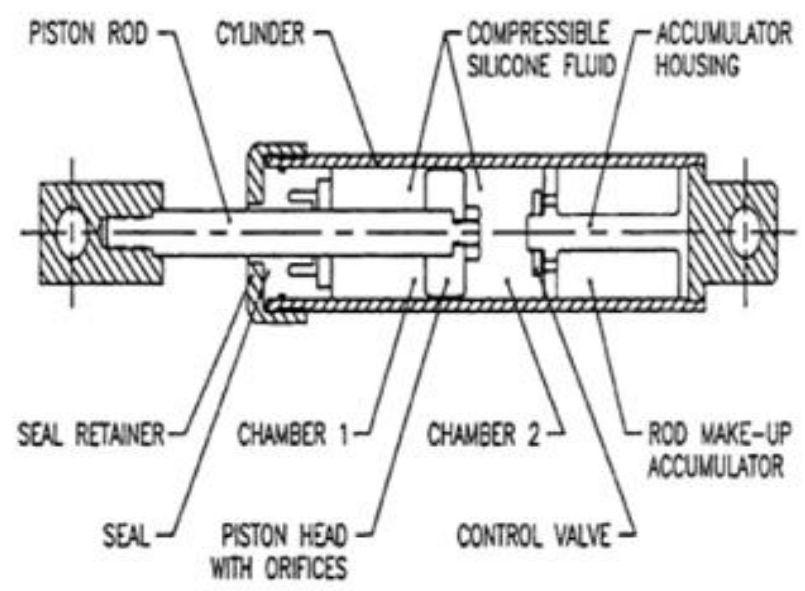

Published By: 


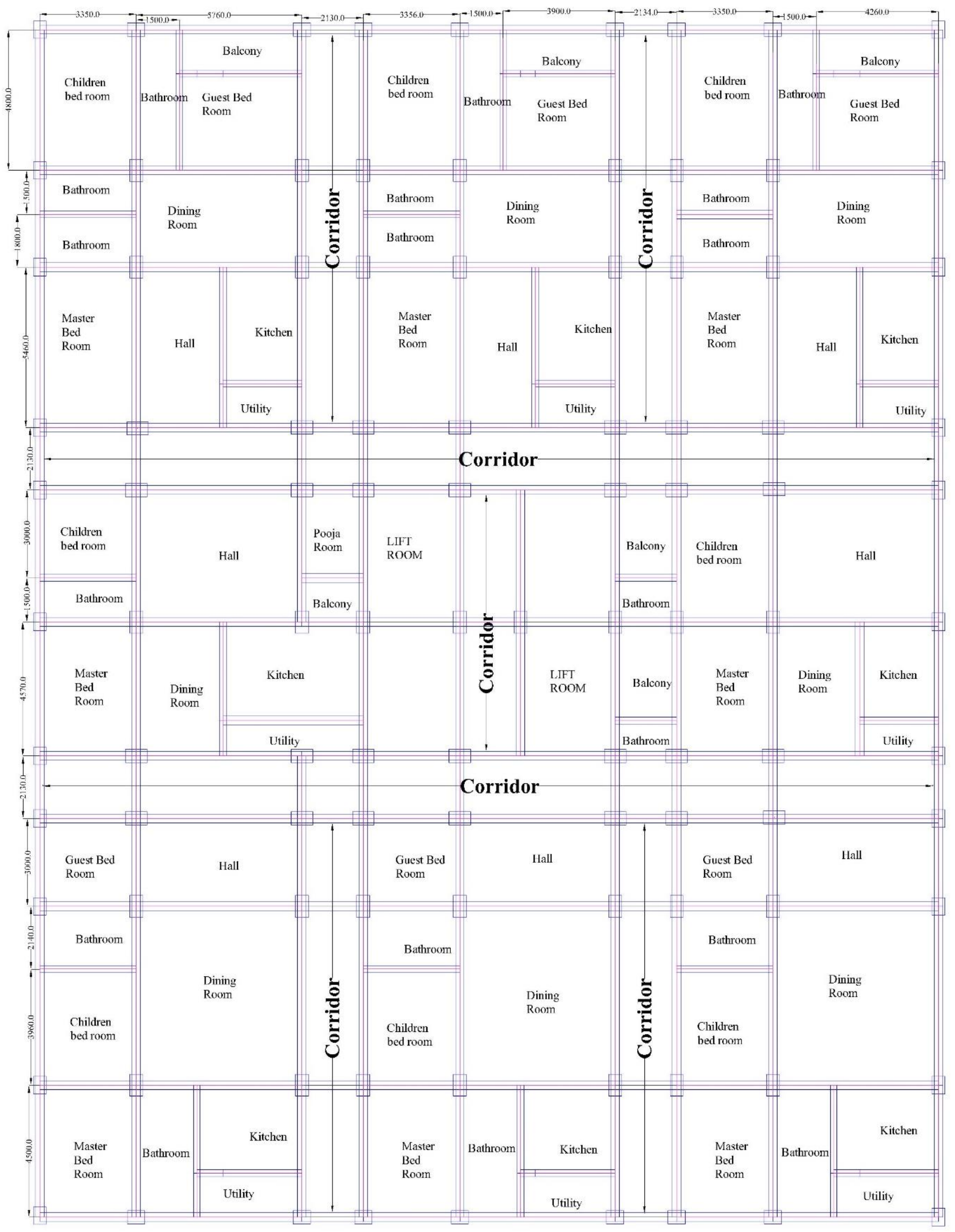

Fig.1. Cross Section of Fluid Viscous Damper

Retrieval Number: C5674029320/2020@BEIESP

DOI: 10.35940/ijeat.C5674.029320

Journal Website: $w$ ww.ijeat.org
Published By:

2233 Blue Eyes Intelligence Engineering

\& Sciences Publication 


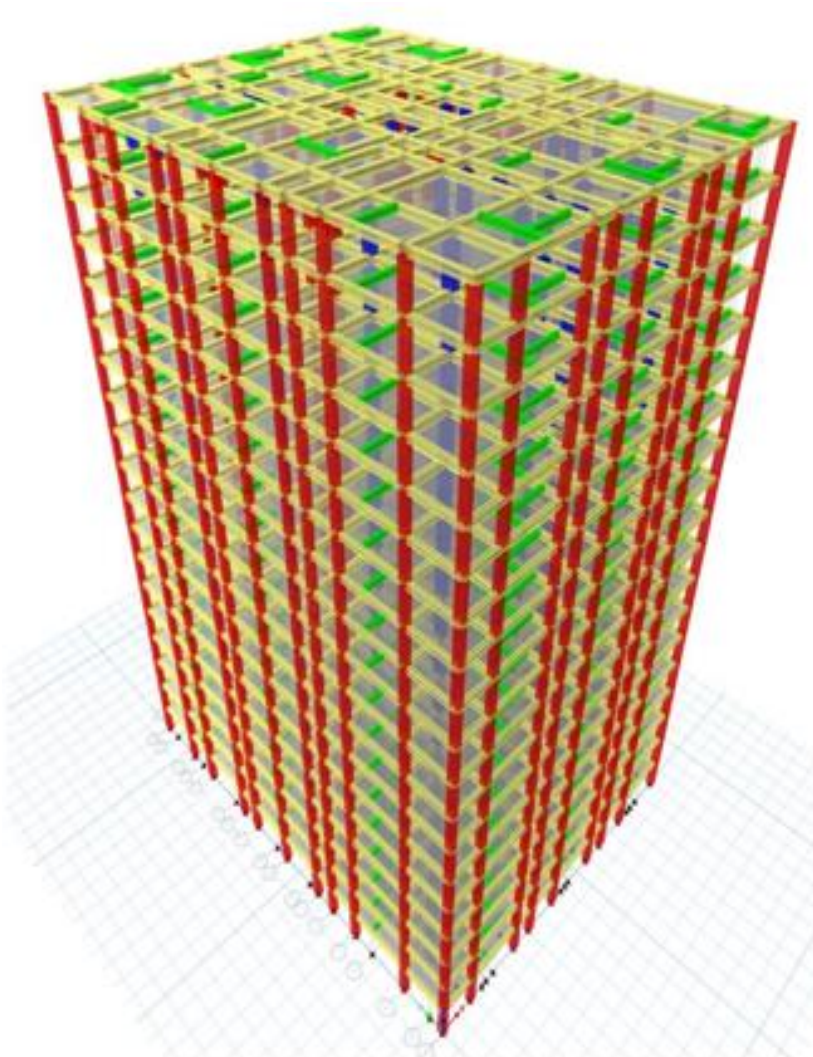

Fig.3. Isometric view of the G+19 RCC framed Structure.

\section{RESULTS AND DISCUSSIONS}

\section{A. Natural Time Period}

Table-I: Values and percentage reduction of the natural time period for different modes with and without dampers.

\begin{tabular}{|c|c|c|c|c|c||c|c|c|}
\hline \multirow{2}{*}{ Mode } & \multicolumn{3}{|c|}{ Time Period (secs) } & \multicolumn{2}{c||}{$\begin{array}{c}\text { Percentage change of } \\
\text { Time Period }\end{array}$} & \multicolumn{3}{c|}{ Frequency (Hz) } \\
\cline { 2 - 9 } & Without Dampers & $\begin{array}{c}\text { With } \\
\text { Linear } \\
\text { FVD's }\end{array}$ & $\begin{array}{c}\text { With Non- } \\
\text { Linear } \\
\text { FVD's }\end{array}$ & $\begin{array}{c}\text { With } \\
\text { Linear } \\
\text { FVD's }\end{array}$ & $\begin{array}{c}\text { With Non- } \\
\text { Linear } \\
\text { FVD's }\end{array}$ & $\begin{array}{c}\text { Without } \\
\text { Dampers }\end{array}$ & $\begin{array}{c}\text { With } \\
\text { Linear } \\
\text { FVD's }\end{array}$ & $\begin{array}{c}\text { With } \\
\text { Non- } \\
\text { Linear } \\
\text { FVD's }\end{array}$ \\
\hline 1 & 2.257 & 0.5 & 1.98 & $77.84 \%$ & $12.27 \%$ & 0.443 & 2 & 0.505 \\
\hline 2 & 2.114 & 0.497 & 1.86 & $76.49 \%$ & $12.01 \%$ & 0.473 & 2.01 & 0.537 \\
\hline 3 & 1.922 & 0.492 & 1.8 & $74.40 \%$ & $6.35 \%$ & 0.52 & 2.03 & 0.556 \\
\hline 4 & 0.737 & 0.17 & 1.793 & $76.93 \%$ & $-143.28 \%$ & 1.356 & 5.88 & 0.558 \\
\hline 5 & 0.689 & 0.164 & 1.364 & $76.19 \%$ & $-97.96 \%$ & 1.452 & 6.1 & 0.733 \\
\hline 6 & 0.631 & 0.155 & 0.54 & $75.43 \%$ & $14.42 \%$ & 1.584 & 6.45 & 1.851 \\
\hline 7 & 0.423 & 0.138 & 0.523 & $67.37 \%$ & $-23.64 \%$ & 2.366 & 7.25 & 1.911 \\
\hline 8 & 0.392 & 0.134 & 0.398 & $65.81 \%$ & $-1.53 \%$ & 2.553 & 7.46 & 2.515 \\
\hline 9 & 0.367 & 0.119 & 0.276 & $67.57 \%$ & $24.79 \%$ & 2.724 & 8.4 & 3.618 \\
\hline 10 & 0.29 & 0.118 & 0.26 & $59.31 \%$ & $10.34 \%$ & 3.446 & 8.47 & 3.84 \\
\hline 11 & 0.27 & 0.109 & 0.198 & $59.62 \%$ & $26.66 \%$ & 3.701 & 9.17 & 5.046 \\
\hline 12 & 0.253 & 0.103 & 0.176 & $59.28 \%$ & $30.43 \%$ & 3.948 & 9.71 & 5.68 \\
\hline 13 & 0.215 & 0.1 & 0.161 & $53.48 \%$ & $25.11 \%$ & 4.644 & 10 & 6.203 \\
\hline 14 & 0.202 & 0.099 & 0.157 & $50.99 \%$ & $22.27 \%$ & 4.962 & 10.1 & 6.36 \\
\hline 15 & 0.189 & 0.098 & 0.139 & $48.14 \%$ & $26.45 \%$ & 5.291 & 10.2 & 7.182 \\
\hline
\end{tabular}

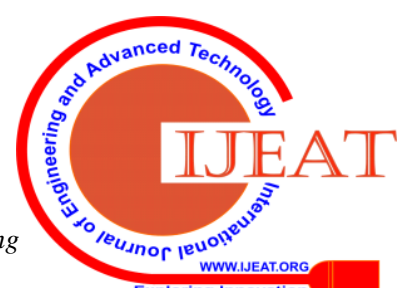




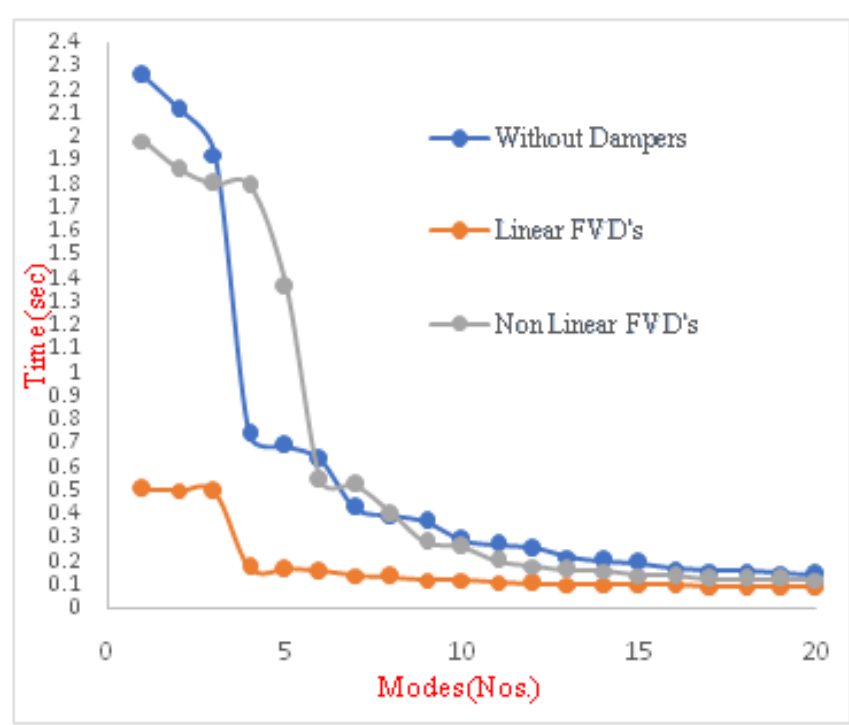

Fig.4. Variation of Natural Time Period profile for all storeys of the building with and without different types of FVD's.

From the Table I and Figure 4, it can be observed that after the incorporation of Fluid Viscous Dampers time period is decreased by $77.84 \%, 76.49 \%, 74.40 \%$ and so on for Linear FVD's and $12.27 \%, 12.01 \%,-143.284 \%,-97.96 \%$ and so on is observed for Non-Linear FVD's. Stiffness of the building is directly proportional to its natural frequency and hence inversely proportional to the natural time period.

\section{B. Base Shear}

Table II Values and percentage reduction of seismic base shear for the building with and without dampers as per IS 1893 (Part 1) - 2016.

\begin{tabular}{|c|c|c|c|c|c|c|c|c|c|}
\hline \multicolumn{2}{|c|}{$\begin{array}{l}\text { Without } \\
\text { Dampers }\end{array}$} & \multicolumn{4}{|c|}{ With Linear FVD's } & \multicolumn{4}{|c|}{ With Non-Linear FVD's } \\
\hline \multirow{2}{*}{$\begin{array}{l}v_{b_{x}} \\
(k N)\end{array}$} & \multirow{2}{*}{$\begin{array}{l}v_{b y} \\
(k N)\end{array}$} & \multirow{2}{*}{$\begin{array}{l}v_{b_{x}} \\
(k N)\end{array}$} & $\begin{array}{c}\% \\
\text { Diff }\end{array}$ & \multirow{2}{*}{$\begin{array}{l}v_{b_{y}} \\
(k N)\end{array}$} & $\begin{array}{c}\% \\
\text { Diff }\end{array}$ & \multirow{2}{*}{$\begin{array}{l}v_{b_{x}} \\
(k N)\end{array}$} & $\begin{array}{c}\% \\
\text { Diff }\end{array}$ & \multirow{2}{*}{$\begin{array}{l}v_{b_{y}} \\
(k N)\end{array}$} & $\begin{array}{c}\% \\
\text { Diff }\end{array}$ \\
\hline & & & & & & & & & \\
\hline 3404 & 3331 & 2456 & $28 \%$ & 2622 & $21 \%$ & 3134 & $8 \%$ & 3121 & $6 \%$ \\
\hline
\end{tabular}

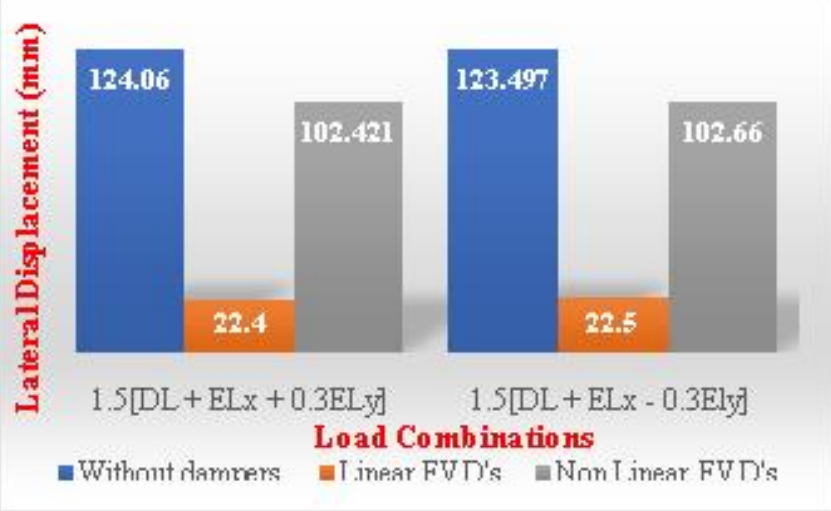

Fig.5. Variation of Seismic Base Shear profile for the building as per the Seismic Code IS 1893(Part 1) - 2016 with and without different types of FVD's.

From the Table II and Figure 5 it can be observed that after the incorporation of Linear Fluid Viscous dampers, base shear is decreased by $28 \%$ in $\mathrm{X}$-direction, $21 \%$ in $\mathrm{Y}$ direction and upon incorporating Non-Linear Fluid Viscous dampers, base shear is decreased by $8 \%$ in $\mathrm{X}$-direction and $6 \%$ in $\mathrm{Y}$-direction.

\section{Lateral Displacement}

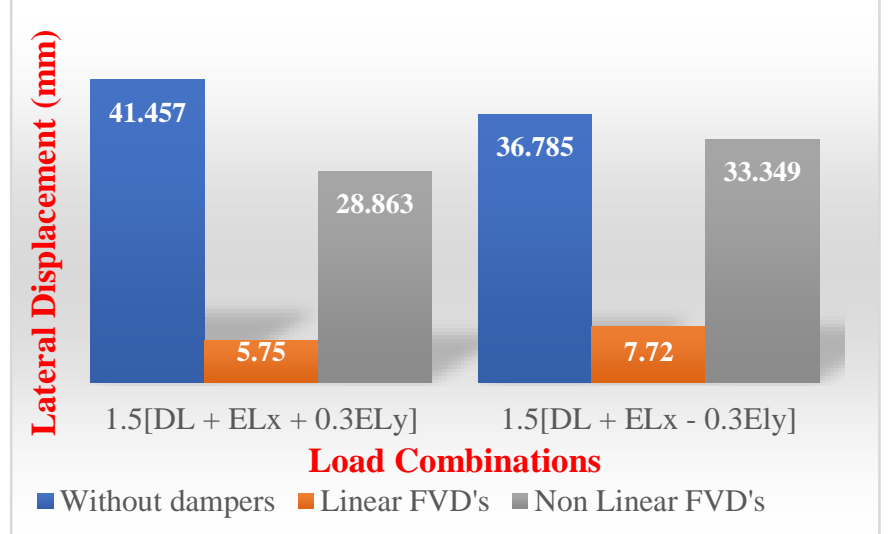

Fig.6. Maximum Lateral Displacement Profile in XDirection for various Load Combinations

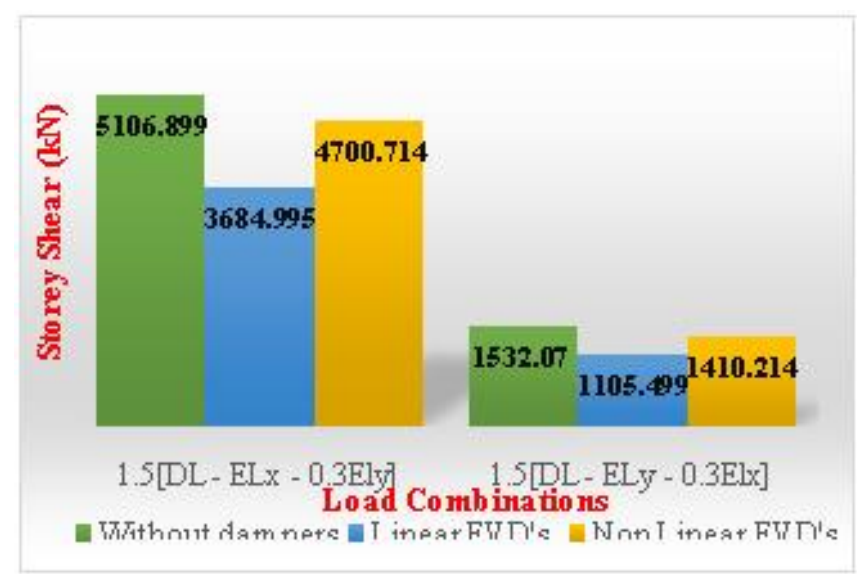

Fig.7. Maximum Lateral Displacement Profile in YDirection for various Load Combinations

From the Figures 6 and 7, it is observed that the Lateral displacement for the building with FVD's and without FVD's, the building without FVD's has been displaced more than the building with any FVD's both in Transverse direction and Longitudinal direction. The Linear FVD's reduced the displacement from $80 \%$ to $92 \%$ of the actual displacement which impacts the structural behaviour. Use of Non-Linear FVD's reduced the displacement from $1 \%$ to $50 \%$ of the actual displacement but followed an irregular pattern of control of displacement leading to even increase of actual displacement in a few cases.

\section{Storey Drift}

From Figures 8 and 9, it is observed, the building without FVD's has drifted more than building installed with any FVD's both in Transverse direction and Longitudinal direction. The Linear FVD's reduced the drift from 54\% to $91 \%$ of the actual drift which impacts the structural behaviour. Use of Non-Linear FVD's reduced the drift from $1 \%$ to $34 \%$ of the actual drift but followed an irregular pattern of control of drift leading to even increase of actual drift in a few cases.

\section{Published By:}




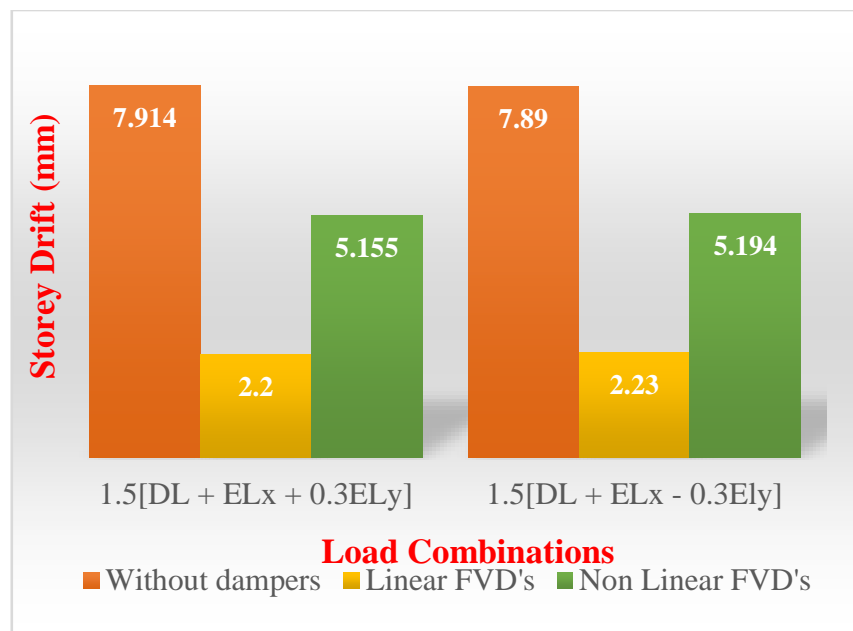

Fig.8. Maximum Storey Drift Profile in X-Direction for various Load Combinations

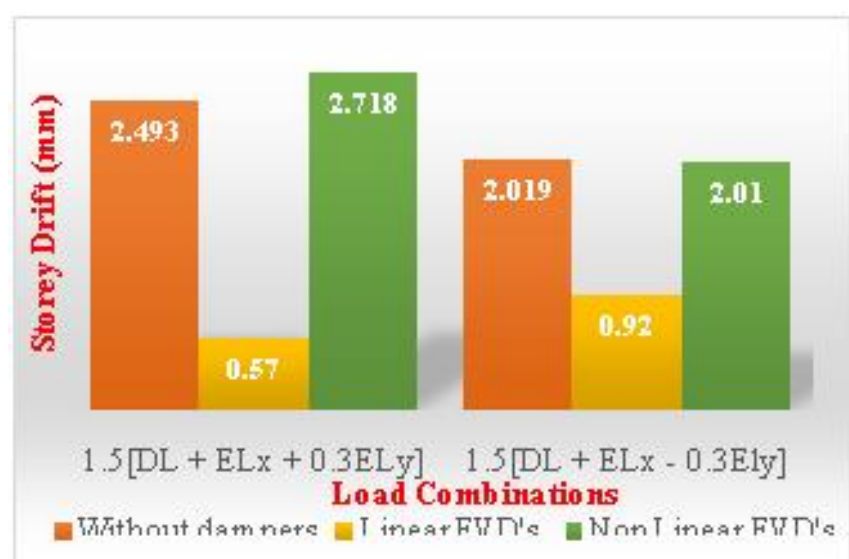

Fig.9. Maximum Storey Drift Profile in Y-Direction for various Load Combinations

E. Storey Shear

From Figures 10 and 11, it is observed, the building without FVD's has more Shear than the building with any FVD's both in Transverse direction and Longitudinal direction. The Linear FVD's reduced the Storey Shear from $20 \%$ to $70 \%$ of the actual shear which reduces the sway in the structure. Use of Non-Linear FVD's reduced the Shear from $1 \%$ to $10 \%$ of the actual shear.

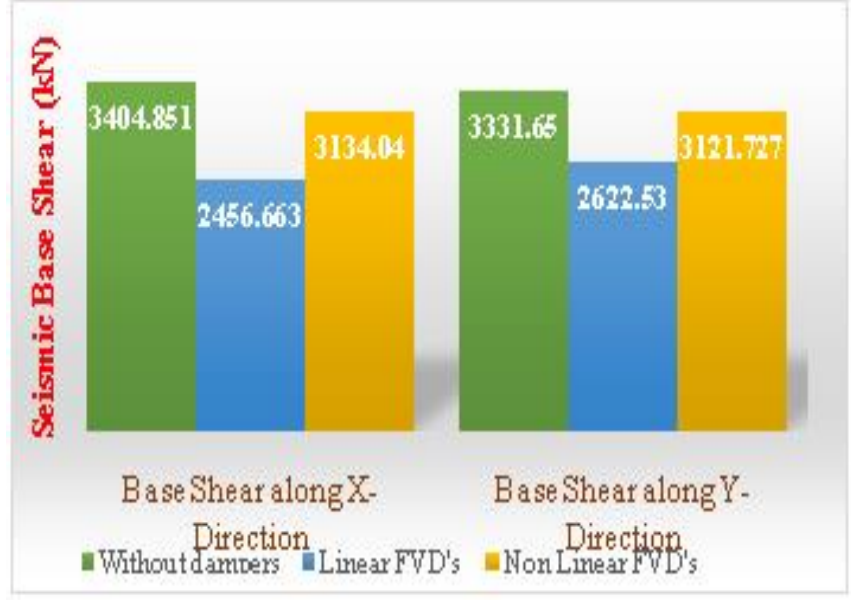

Fig.10. Maximum Storey Shear Profile in X-Direction for various Load Combinations.

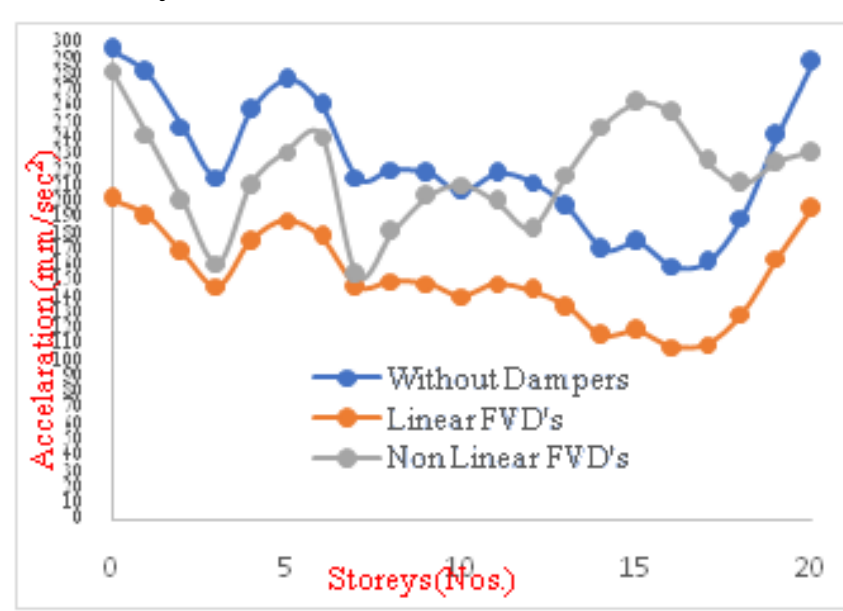

Fig.12. Maximum Storey Acceleration (mm/sec2) profile for all storeys of the for Time History Analysis of Chile Earthquake Data.

It can be clearly observed that there is a reduction in Acceleration upon using the Linear FVD's. The Non-Linear FVD's are not only reducing the Acceleration but they even increased the Acceleration in few cases which impacted the whole performance of the structure.

\section{G. Time History Analysis}

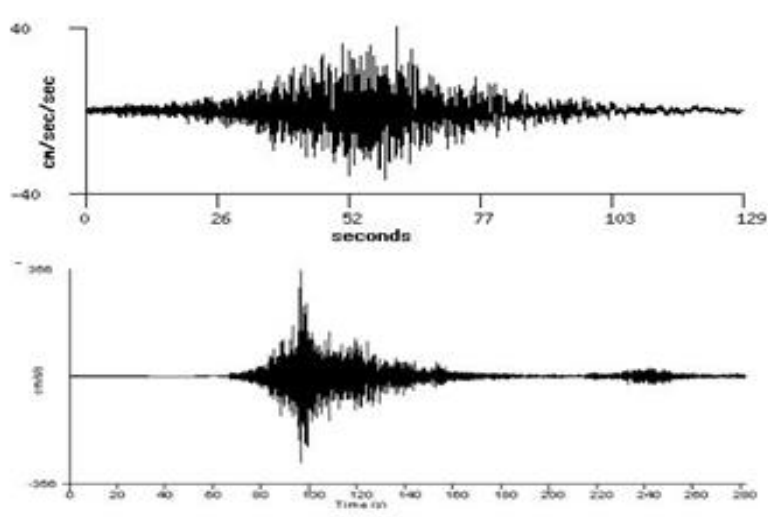

Fig.13. Southern Sumatra Earthquake M8.4 and Iquique, Chile Earthquake M8.2 


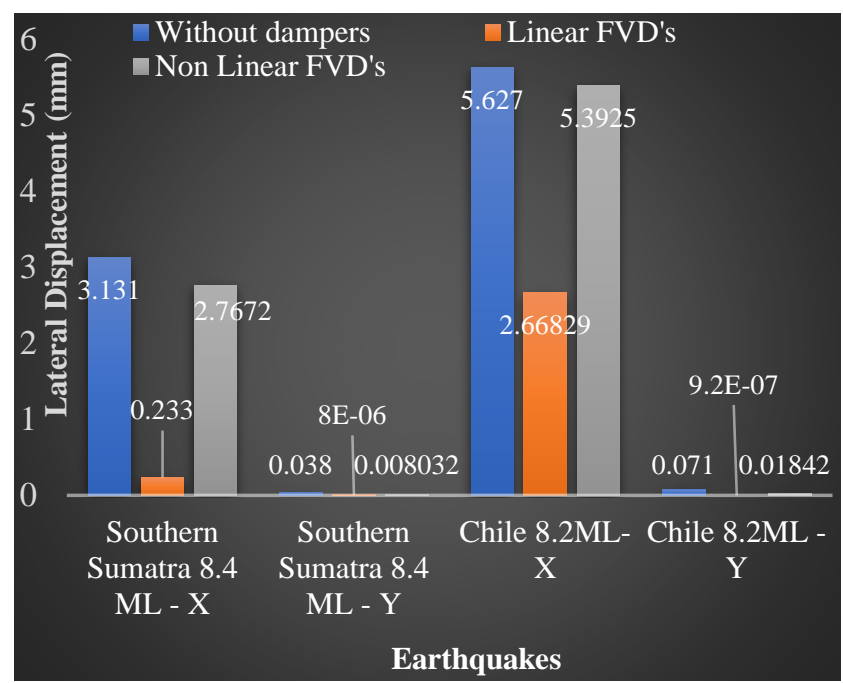

Fig.14. Maximum Positive Base Shear $(k N)$ under the Influence of Earthquakes ( Time History Data)

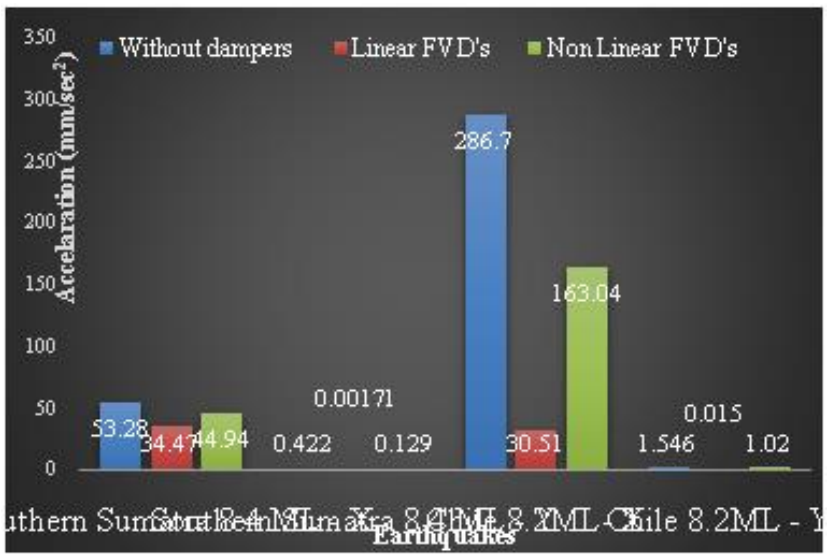

Fig.15. Maximum Positive Lateral Displacement (mm) under the Influence of Earthquakes (Time History Data)

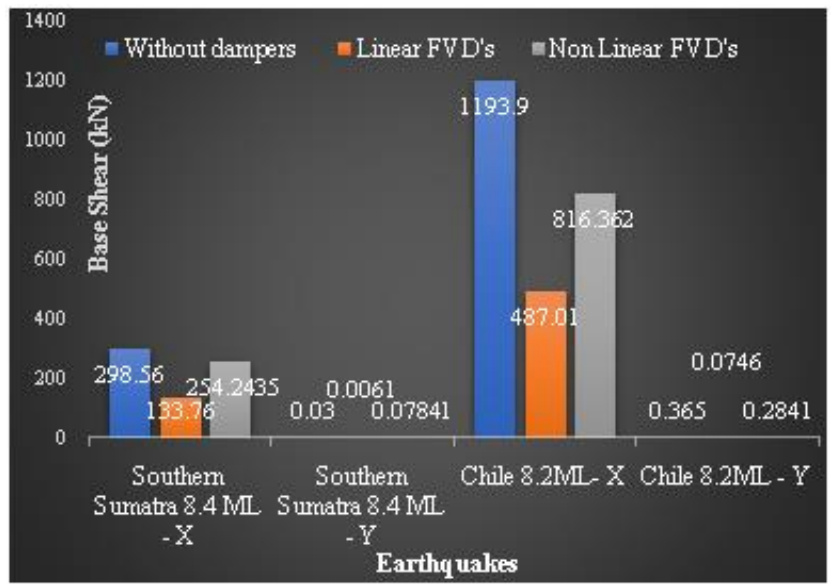

Fig.16. Maximum Positive Acceleration (mm/sec2) under the Influence of Earthquakes (Time History Data)

Table III Maximum Time History Responses for the building under the Influence of Chile and Southern Sumatra Earthquake

\begin{tabular}{|c|c|c|c|c|c|c|c|c|c|}
\hline \multicolumn{10}{|c|}{ Maximum Time History Responses } \\
\hline \multirow[t]{2}{*}{ S.No } & \multirow[t]{2}{*}{$\begin{array}{l}\text { Structural } \\
\text { Response }\end{array}$} & \multirow[t]{2}{*}{ Earthquakes } & $\begin{array}{c}\text { Time } \\
\text { (nth } \\
\text { Second) }\end{array}$ & Direction & $\begin{array}{l}\text { Without } \\
\text { Dampers }\end{array}$ & $\begin{array}{l}\text { Linear } \\
\text { FVD's }\end{array}$ & $\begin{array}{c}\% \\
\text { Reduction }\end{array}$ & $\begin{array}{l}\text { Non- } \\
\text { Linear } \\
\text { FVD's }\end{array}$ & $\begin{array}{c}\% \\
\text { Reduction }\end{array}$ \\
\hline & & & & & $\mathrm{mm}$ & $\mathrm{mm}$ & & $\mathrm{mm}$ & \\
\hline \multirow{8}{*}{1} & \multirow{8}{*}{ Base Shear } & \multirow{4}{*}{$\begin{array}{c}\text { Southern Sumatra } 8.4 \\
\text { ML }\end{array}$} & 245.1 & $\mathrm{X}$ & 298.56 & 133.76 & $55.20 \%$ & 254.24 & $14.84 \%$ \\
\hline & & & 203.7 & $\mathrm{Y}$ & 0.03 & 0.006 & $79.67 \%$ & 0.07 & $-161.37 \%$ \\
\hline & & & 246 & $(-X)$ & -165.01 & -116.2 & $29.58 \%$ & -155.32 & $5.87 \%$ \\
\hline & & & 221 & $(-Y)$ & -0.038 & -0.006 & $84.08 \%$ & -0.02 & $27.87 \%$ \\
\hline & & \multirow{4}{*}{ Chile 8.2ML } & 193.1 & $\mathrm{X}$ & 1193.9 & 487.01 & $59.21 \%$ & 816.36 & $31.62 \%$ \\
\hline & & & 187.4 & $\mathrm{Y}$ & 0.36 & 0.07 & $79.56 \%$ & 0.28 & $22.16 \%$ \\
\hline & & & 199.4 & $(-X)$ & -431.22 & -180.06 & $58.24 \%$ & -395.86 & $8.20 \%$ \\
\hline & & & 198.8 & $(-Y)$ & -0.38 & -0.07 & $81.77 \%$ & -0.34 & $10.99 \%$ \\
\hline
\end{tabular}




\begin{tabular}{|c|c|c|c|c|c|c|c|c|c|}
\hline \multirow{8}{*}{2} & \multirow{8}{*}{$\begin{array}{c}\text { Lateral } \\
\text { Displacement }\end{array}$} & \multirow{4}{*}{$\begin{array}{c}\text { Southern Sumatra } 8.4 \\
\text { ML }\end{array}$} & 246.5 & $\mathrm{X}$ & 3.13 & 0.23 & $92.56 \%$ & 2.76 & $11.62 \%$ \\
\hline & & & 225.5 & $\mathrm{Y}$ & 0.03 & 0.000008 & $99.98 \%$ & 0.008 & $78.86 \%$ \\
\hline & & & 245.3 & $(-X)$ & -5.33 & -0.41 & $92.25 \%$ & -4.38 & $17.76 \%$ \\
\hline & & & 248.1 & $(-Y)$ & -0.04 & -0.00001 & $99.98 \%$ & -0.007 & $81.79 \%$ \\
\hline & & \multirow{4}{*}{ Chile 8.2ML } & 199.9 & $\mathrm{X}$ & 5.62 & 2.66 & $52.58 \%$ & 5.392 & $4.17 \%$ \\
\hline & & & 197.5 & $\mathrm{Y}$ & 0.07 & 0.000009 & $99.99 \%$ & 0.01 & $74.06 \%$ \\
\hline & & & 193.2 & $(-X)$ & -16.55 & -3.86 & $76.67 \%$ & -14.09 & $14.82 \%$ \\
\hline & & & 196.4 & $(-Y)$ & -0.14 & -0.0001 & $99.93 \%$ & -0.02 & $85.34 \%$ \\
\hline \multirow{8}{*}{3} & \multirow{8}{*}{ Acceleration } & \multirow{4}{*}{$\begin{array}{c}\text { Southern Sumatra } 8.4 \\
\text { ML }\end{array}$} & 224 & $\mathrm{X}$ & 53.28 & 34.47 & $35.30 \%$ & 44.94 & $15.65 \%$ \\
\hline & & & 257 & $\mathrm{Y}$ & 0.42 & 0.001 & $99.59 \%$ & 0.129 & $69.43 \%$ \\
\hline & & & 245 & $(-X)$ & -45.04 & -40.75 & $9.52 \%$ & -43.22 & $4.04 \%$ \\
\hline & & & 246.2 & $(-Y)$ & -0.34 & -0.001 & $99.62 \%$ & -0.13 & $62.29 \%$ \\
\hline & & \multirow{4}{*}{ Chile 8.2ML } & 193.1 & $\mathrm{X}$ & 286.7 & 30.51 & $89.36 \%$ & 163.04 & $43.13 \%$ \\
\hline & & & 196.7 & $\mathrm{Y}$ & 1.54 & 0.015 & $99.03 \%$ & 1.02 & $34.02 \%$ \\
\hline & & & 192.6 & $(-X)$ & -304.43 & -43.9 & $85.58 \%$ & -295.9 & $2.80 \%$ \\
\hline & & & 193.6 & $(-Y)$ & -1.922 & -0.02 & $98.70 \%$ & -1.27 & $33.93 \%$ \\
\hline
\end{tabular}

With the Application of Linear FVD, there is $80 \%$ to 99\% decrease in Lateral Displacement, Base Shear, Acceleration in the structure under different Earthquake Time History conditions Chile $8.2 \mathrm{M}$ and Southern Sumatra 8.4 M.

Table IV Maximum Damper Deformation under influence of Earthquakes

\begin{tabular}{|c|c|c|c|}
\hline \multicolumn{4}{|c|}{ Damper Deformation } \\
\hline $\begin{array}{c}\text { Damper } \\
\text { Number }\end{array}$ & Name of Earthquake & $\begin{array}{c}\text { Positive } \\
\text { Displacement } \\
(\mathbf{m m})\end{array}$ & $\begin{array}{c}\text { Negative } \\
\text { Displacement } \\
(\mathbf{m m})\end{array}$ \\
\hline \multirow{2}{*}{ K259 } & Chile Earthquake & $1.30 \mathrm{E}-06$ & $-1.60 \mathrm{E}-06$ \\
\cline { 2 - 4 } & $\begin{array}{c}\text { Southern Sumatra } \\
\text { Earthquake }\end{array}$ & $1.00 \mathrm{E}-06$ & $-4.00 \mathrm{E}-06$ \\
\hline & Chile Earthquake & $2.90 \mathrm{E}-04$ & $-3.00 \mathrm{E}-05$ \\
\hline \multirow{2}{*}{ K279 } & $\begin{array}{c}\text { Southern Sumatra } \\
\text { Earthquake }\end{array}$ & $4.00 \mathrm{E}-06$ & $-2.00 \mathrm{E}-06$ \\
\cline { 2 - 4 } & \multicolumn{3}{|c}{} \\
\hline
\end{tabular}

Fig.18. Damper (K259) Deformation under the influence of the Chile Earthquake.

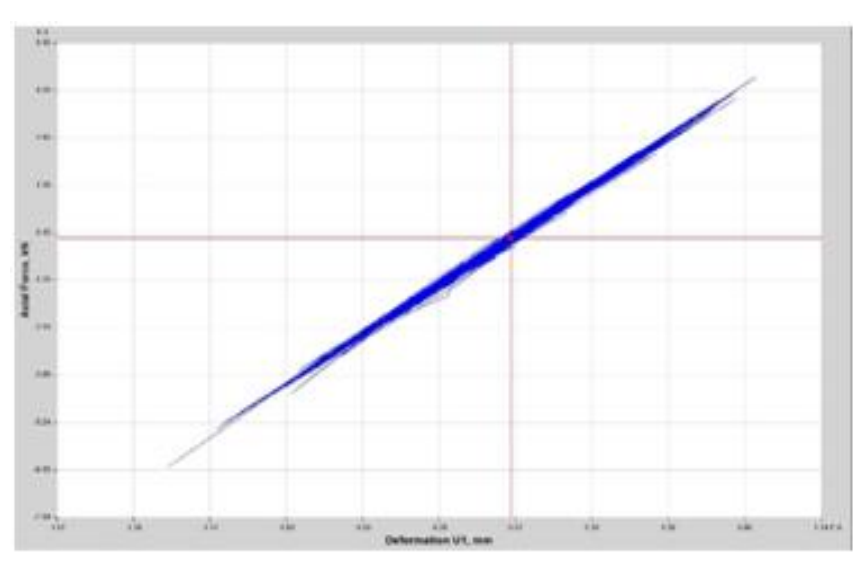

Fig.17. Damper (K259) Deformation under the influence of Southern Sumatra Earthquake

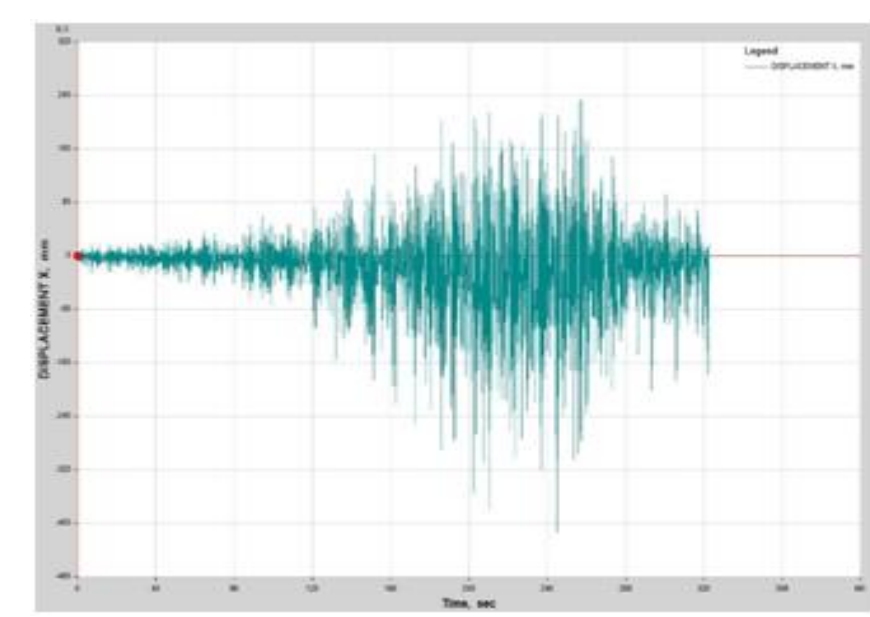

Fig.19. Base Shear $X$ vs Time, under the influence of Southern Sumatra Earthquake 


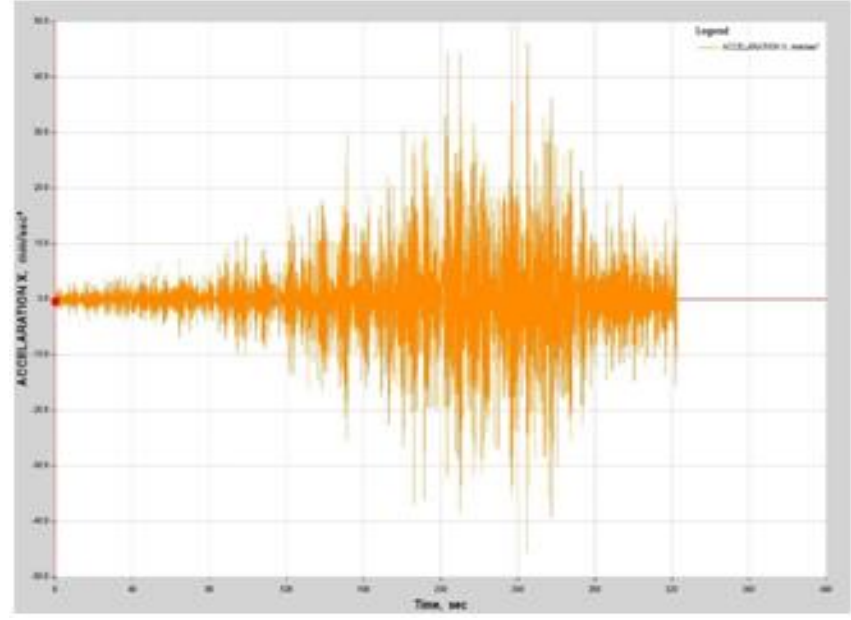

Fig.20. Lateral Displacement $X$ vs Time, under the influence of Southern Sumatra Earthquake

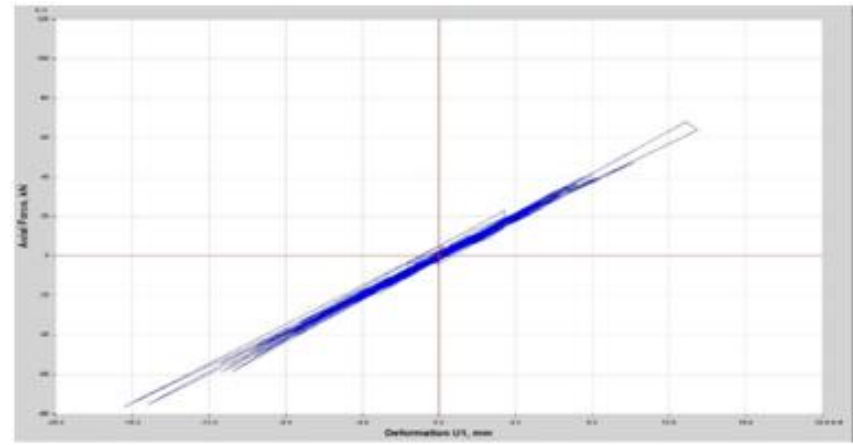

Fig.21. Acceleration $X$ vs Time, under the influence of Southern Sumatra Earthquake

\section{CONCLUSIONS}

The present study is focused on the influence of linearly varying and Non-linearly varying fluid viscous dampers on seismic performance of a building located in the seismic zone V of India. The Performance of the building is studied in terms of Natural time period, base shear, lateral displacements, storey drifts, storey shears and Time-history responses.

The seismic analysis is carried out by Response spectrum method and Time History analysis is done with Chile 8.2 M and Southern Sumatra 8.4 M for G+19 storey residential building. The following are the conclusions that can be drawn from the present study.

1. Energy is dissipated by the fluid viscous dampers, that act like a fuse which limits the forces acting on the structure, rather than by the inelasticity of structural members.

2. The natural time period of the structure decreases with the use of Linear viscous damper by $77.84 \%$ and with Non-linear Viscous damper by $12.27 \%$ and hence stiffness of the structure increases by the use of Linear Viscous damper when compared to the Non-linear Viscous damper.

3. The seismic base shear decreased by $28 \%$ for structure with linear FVD and by $8 \%$ for structure with Nonlinear FVD when compared to that of the structure without damper.

4. The lateral displacement of the structure with Linear FVD decreased by $80 \%$ to $92 \%$ and $1 \%$ to $50 \%$ for
Non-linear FVD when compared to the lateral displacements of the structure without damper.

5. The Storey drift of the structure decreased by $54 \%$ to 91\% with Linear FVD and 1\% to 34\% for Non-linear FVD when compared to the Storey drift of structure without damper.

6. The Storey shear of the structure decreased by $20 \%$ to $70 \%$ with Linear FVD and $7 \%$ to $10 \%$ with Non-linear FVD when compared to the Storey shear of the structure without damper.

7. The Storey acceleration of the structure with Linear FVD decreased by $32 \%$ when compared to the Storey acceleration of structure without damper.

8. The Storey acceleration of the structure with NonLinear FVD varied between $-60 \%$ to $20 \%$ when compared to the Storey shear of the structure without damper.

9. With the use of Linear FVD, there is $80 \%$ to $99 \%$ decrease in Lateral Displacement, Base Shear, Acceleration in the structure under different Earthquake Time History conditions - Chile 8.2 M and Southern Sumatra 8.4 M.

From the study, it is concluded that performance of the structure is better when the energy is dissipated by Linear FVD's when compared to Non-Linear FVD's when considering the Linear FVD's are placed at the central bay of the Elevation of building on all sides.

\section{REFERENCES}

1. M.C. Constantinou, P. Tsopelas, W. Hammel, A.N. Sigaher, Togglebrace-damper seismic energy dissipation systems, J. Struct. Eng. ASCE 127 (2) (2001) 105-112.

2. T. Soong, B. Spencer, Supplemental energy dissipation: state-of-theart and state-of-the-practice, Eng. Struct. 24 (3) (2002) 243-259.

3. I. Takewaki, Building Control with Passive Dampers: Optimal Performance-based Design for Earthquakes, John Wiley \& Sons, 2011.

4. Y. Bozorgnia, V.V. Bertero, Earthquake Engineering: From Engineering Seismology to Performance-based Engineering, CRC Press, 2004.

5. M. Constantinou, M. Symans, Experimental study of seismic response of buildings with supplemental fluid dampers, Struct Des Tall Spec Build. 2 (2) (1993) 93-132.

6. M. Constantinou, M. Symans, D. Taylor, Fluid viscous damper for improving the earthquake resistance of buildings, Proceedings of the Symposium on Structural Engineering in Natural Hazards Mitigation, 1993.

7. J. Kim, J. Lee, H. Kang, Seismic retrofit of special truss moment frames using viscous dampers, J. Constr. Steel Res. 123 (2016) 5367.

8. M. Martinez-Rodrigo, M. Romero, an optimum retrofit strategy for moment resisting frames with nonlinear viscous dampers for seismic applications, Eng. Struct. 25 (7) (2003) 913-925.

9. C. Tsai, C.-L. Ho, C.-W. Chang, K.-C. Chen, Experimental investigation on steel structures equipped with a fluid viscous damper, ASME-PUBLICATIONS-PVP, Vol. 428 2001, pp. 95-102.

10. E. Tubaldi, M. Barbato, A. Dall'Asta, Performance-based seismic risk assessment for buildings equipped with linear and nonlinear viscous dampers, Eng. Struct. 78 (2014) 9099.

11. P. Uriz, A. Whittaker, Retrofit of pre-Northridge steel momentresisting frames using fluid viscous dampers, Struct Des Tall Spec Build 10 (5) (2001) 371-390.

12. M. Dicleli, A. Mehta, Seismic performance of chevron braced steel frames with and without viscous fluid dampers as a function of ground motion and damper characteristics, J. Constr. Steel Res. 63 (8) (2007) 1102-1115. 
13. C.Y. Seo, T.L. Karavasilis, J.M. Rickles, R. Sause, Seismic performance and probabilistic collapse resistance assessment of steel moment-resisting frames with fluid viscous dampers, Earthq. Eng. Struct. Dyn. 43 (14) (2014) 2135-2154.

14. J. Gluck, Y. Ribakov, Active viscous damping system with amplifying braces for control of MDOF structures, Earthq. Eng. Struct. Dyn. 31 (9) (2002) 1735-1751.

15. J.-D. Kang, H. Tagawa, Seismic performance of steel structures with seesaw energy dissipation system using fluid viscous dampers, Eng. Struct. 56 (2013) 431-442.

16. Y. Ribakov, A.M. Reinhorn, Design of amplified structural damping using optimal considerations, J. Struct. Eng. ASCE 129 (10) (2003) 1422-1427.

17. A.N. Sigaher, M.C. Constantinou, Scissor-jack-damper energy dissipation system, Earthquake Spectra 19 (1) (2003) 133-158.

18. M. Mansoori, A. Moghadam, Using viscous damper distribution to reduce multiple seismic responses of asymmetric structures, J. Constr. Steel Res. 65 (12) (2009) 2176-2185.

19. X.W. Chen, J.X. Li, J. Cheang, Seismic performance analysis of Wenchuan Hospital structure with viscous dampers, Struct Des Tall Spec Build 19 (4) (2010) 397-419.

20. Y. Fu, K. Kasai, Comparative study of frames using viscoelastic and viscous dampers, J. Struct. Eng. ASCE 124 (5) (1998) 513-522.

21. N. Gluck, A. Reinhorn, J. Gluck, R. Levy, Design of supplemental dampers for control of structures, J. Struct. Eng. ASCE 122 (12) (1996) 1394-1399.

22. K. Kasai, Y. Fu, A. Watanabe, Passive control systems for seismic damage mitigation, J. Struct. Eng. ASCE 124 (5) (1998) 501-512.

23. D. Lee, D.P. Taylor, Viscous damper development and future trends, Struct Des Tall Spec Build 10 (5) (2001) 311-320.

24. Y.-Y. Lin, M. Tsai, J. Hwang, K. Chang, Direct displacement-based design for building with passive energy dissipation systems, Eng. Struct. 25 (1) (2003) 25-37.

25. C.A. Martínez, O. Curadelli, M.E. Compagnoni, Optimal design of passive viscous damping systems for buildings under seismic excitation, J. Constr. Steel Res. 90 (2013) 253-264.

26. K. Uetani, M. Tsuji, I. Takewaki, Application of an optimum design method to practical building frames with viscous dampers and hysteretic dampers, Eng. Struct. 25 (5) (2003) 579-592.

27. J. Yang, S. Lin, J.H. Kim, A. Agrawal, Optimal design of passive energy dissipation systems based on $\mathrm{H} \infty$ and $\mathrm{H} 2$ performances, Earthq. Eng. Struct. Dyn. 31 (4) (2002) 921-936.

28. Code requirements for the design and implementation of passive energy dissipation systems, in: A. Whittaker, I. Aiken, D. Bergman, P. Clark, J. Cohen, J. Kelly, et al. (Eds.), Proc, of ATC 17-l Seminar on Seismic Isolation, Passive Energy Dissipation, and Active Control, 1993.

29. ASCE. American Society of Civil Engineers, Minimum design loads for buildings and other structures, Reston (VA): ASCE/SEI 7-10, 2010.

30. J.-S. Hwang, Y.-N. Huang, S.-L. Yi, S.-Y. Ho, Design formulations for supplemental viscous dampers to building structures, J. Struct. Eng. ASCE 134 (1) (2008) 22-31.

31. Federal Emergency Management Agency, FEMA 451: NEHRP Recommended Provisions: Design Examples. Washington (DC), (2006).

32. Mehdi Banazadeh, Ali Ghanbari, Reza Ghanbari (2017) Seismic performance assessment of steel moment-resisting frames equipped with linear and nonlinear fluid viscous dampers with the same damping ratio. Elsevier Journal of Constructional Steel Research 136 (2017) 215-228. http://dx.doi.org/10.1016/j.jcsr.2017.05.022

\section{AUTHORS PROFILE}

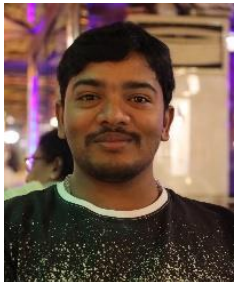

Sai Gowtham Dasari, completed his bachelor's in Civil Engineering from GITAM University, India. Master's in Structural Engineering from Andhra University, India. He has wide research exposure for 2 years in the field of Structures, Soil and Transportation. He has been currently working in the field of Transportation and Structures in Visakhapatnam, India. He has worked in different student Organisations in bachelors such as IEEE, IEI, EWB, ASCE, ISTE. He even participated in the Open Innovation Challenge Competition in 2016 conducted by UNIVERSITY OF CALIFORNIA, Berkeley. ( Berkeley Haas)

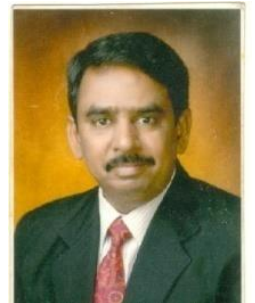

Dr. Srinivas Rao Killamsetti, received his bachelor's, master's in Civil Engineering from Andhra University, India. He received his $\mathrm{PhD}$ in Concrete behaviour at Elevated Temperatures from Andhra University, He has both field and teaching experience of 28 years in Civil. He has published 61 research papers in reputed journals in with ICJ, Scopus, Elsevier, etc. He guided many students in $\mathrm{PhD}$, Masters and Bachelors. He even worked in research projects under UGC and served as Dean and Head of the Structural Division in the Department of Civil, Andhra University. He is currently working as Professor, Civil Department, Andhra University, India. 